\title{
Blood biochemical parameters of broilers fed differently thermal processed soybean meal
}

\author{
Parámetros bioquímicos en sangre de pollos alimentados con \\ harina de soja procesada bajo distintos procesos térmicos
}

\author{
Mojgan Nahavandinejad, ${ }^{1}$ M.Sc, Alireza Seidavi, ${ }^{1 *}$ Ph.D, Leila Asadpour, ${ }^{2}$ Ph.D, \\ Rita Payan-Carreira ${ }^{3}$ Ph.D.
}

\begin{abstract}
${ }^{1}$ Islamic Azad University, Rasht Branch, Department of Animal Science, Rasht, Iran. ${ }^{2}$ Islamic Azad University, Rasht Branch, Department of Veterinary Medicine, Rasht, Iran. ${ }^{3}$ Animal and Veterinary Research Centre-CECAV; Department of Zootecnics, ECAV, UTAD, Vila Real, Portugal. *Correspondence: alirezaseidavi@iaurasht.ac.ir
\end{abstract}

Received: February 2014; Accepted: July 2014.

\begin{abstract}
Objective. A 42-days feeding trial was carried out to evaluate the influences of differently thermal processed soybean meal on the broilers blood biochemical parameters. Materials and methods. A total of 200 male birds of Ross strain were allocated into five different diets formulated using differently heat-treated soybean meals, with ten birds per treatment and per replicate. Diets contained: raw soybean (controls), autoclaved for a short $\left(121^{\circ} \mathrm{C}, 20 \mathrm{~min}\right.$; Aut1 group) or medium length period $\left(121^{\circ} \mathrm{C}, 30 \mathrm{~min}\right.$; Aut2 group) soybean meal, micro-waved soybean meal $\left(46^{\circ} \mathrm{C}, 540 \mathrm{Watt}, 7 \mathrm{~min}\right.$; $\mathrm{McW}$ group) and browned soybean meal $\left(120^{\circ} \mathrm{C}, 20 \mathrm{~min}\right.$; Brn group). Results. Blood serum metabolites showed that all treated diets presented lower lipid metabolism makers and higher protein metabolism markers. Broilers showed increased final body weight when fed heat-treated meals compared with control. Results suggested that thermal treatments altered the lipid metabolism in broilers that might originate a decrease in abdominal fat deposition. Conclusions. Comparison of the results for all the treated groups showed the Aut2 treatment is the most suitable method for soybean thermal treatment processing; in contrast, the Aut1 treatment had the closest results to the control group.
\end{abstract}

Key words: Broiler chicken, cholesterol, processing, soybean meal, total protein (Source: CAB).

\section{RESUMEN}

Objetivo. Se llevó a cabo un estudio de 42 días para determinar la influencia de la introducción de harina de soja sometida a diferentes procesos térmicos sobre los parámetros sanguíneos bioquímicos de pollos de engorde. Materiales y métodos. Un total de 200 pollos machos, de raza Ross, fueron asignados a cinco dietas equivalentes conteniendo harina de soja sometida a diferentes tratamientos térmicos, creando grupos de10 aves por cada tratamiento y por replicado. Los tratamientos térmicos fueron: harina de soja en bruto (Grupo control), harina de soja en autoclave durante un período de tiempo corto $\left(121^{\circ} \mathrm{C}, 20 \mathrm{~min}\right.$; Grupo Aut1) o medio $\left(121^{\circ} \mathrm{C}, 30\right.$ minutos; Grupo Aut2), harina de soja irradiado en el microondas $\left(46^{\circ} \mathrm{C}, 540\right.$ Watts, 7 min; Grupo McW $)$ y harina tostada de soja $\left(120^{\circ} \mathrm{C}\right.$, 20 min; Grupo Brn). Resultados. Todos los grupos de tratamiento mostraron una disminución delos 
niveles de los marcadores de metabolismo de los lípidos y un aumento del metabolismo de la proteína circulante, en comparación con el grupo control. Los pollos alimentados con dietas conteniendo soja tratada mostraron además un aumento en su peso corporal final, en comparación con los del control. Los resultados sugieren que los tratamientos térmicos interfieren con el metabolismo de los lípidos, lo que puede originar una menor deposición de grasa abdominal en los pollos. Conclusiones. La comparación de los datos obtenidos para los diferentes tratamientos térmicos identifica el tratamiento en autoclave (Aut2) como el método más adecuado para el procesamiento de la soja. En contraste, el tratamiento en autoclave (Aut1) demostró ser el método con resultados más semejantes a los del control.

Palabras clave: Dieta deharina de soja; procesamiento; colesterol; proteínas totales; pollos de engorde (Fuente: $C A B$ ).

\section{INTRODUCTION}

Growing of global population is accompanied by an increased demand for continuous and diversified food supply, which drove the need for the production of sufficient, safe, nutritious and affordable food, not only for feeding but also for people wealth. Further, livestock production plays a major social role in developing countries, while providing food, income, employment and many other contributions to rural development.

The structure of the world livestock industry changed accordingly, in several parameters, such as size, intensification, efficiency and genetic background of the animals (1).

Feeding assumed a major importance in poultry production and aims to maintain relatively low prices while increasing poultry meat and egg production. The main aspects targeted in research include the improvement of feed digestibility and feed efficiency (2); the use of least-cost and alternative ingredients in diet formulation; the interaction of feed value and nutrient metabolism on meeting bird requirements (2); influences of feed on the birds immunology and health (3); and the production of a high quality final product meeting the market requirements.

There are several factors that may affect feed and nutrient intake level, and consequently compromise the efficiency of poultry production. Among such factors, the physical form of feed, the feed flavour, the presence of anti-nutritional factors, the changes in the digestive tract microflora and the nutrient absorption are main issues that need attention.

Corn has been gradually changed by soybean in many poultry diets. Soybeans are widely used as protein sources in human and animal diets, but it contains certain anti-nutritional factors (such as the trypsin inhibitor and lectins) that may interfere with protein digestibility and absorption

\section{INTRODUCCIÓN}

El crecimiento de la población global se acompaña de una demanda creciente de un suministro continúo y diversificado de alimentos, lo que impulsó la necesidad de producir cantidades suficientes de alimentos seguros, nutritivos y económicos para alimentar a la población. Además, la producción de aves de corral desempeña un papel social importante en países en vías de desarrollo al proveer comida, ingresos, empleo y muchas otras contribuciones al desarrollo rural.

Por eso la industria agropecuaria a nivel mundial cambió en varios parámetros, tales como tamaño, intensificación, eficiencia y antecedentes genéticos de los animales (1).

La alimentación adquirió una importancia mayor en la producción de aves de corral para mantener precios relativamente bajos mientras aumenta la producción de carne y huevos. Los aspectos principales que fueron el enfoque de la investigación incluyen el mejorar la digestibilidad de los alimentos y la eficiencia alimenticia (2); el uso de ingredientes alternativos y de menor costo en la formulación de dietas; la combinación del valor de la alimentación y el metabolismo de nutrientes para suplir los requisitos de las aves (2); la influencia del alimento en la inmunología y salud de las aves (3); y la producción de un producto final de alta calidad que satisface los requerimientos del mercado.

Hay varios factores que pueden afectar el nivel de la alimentación y la absorción de nutrientes, y que comprometen la eficiencia en la producción de aves. Entres tales factores están la forma física del alimento, el sabor del alimento, la presencia de factores antinutricionales, los cambios en la microflora del aparato digestivo, y la absorción de nutrientes, siendo los principales factores que requieren atención.

En muchas dietas para aves el maíz ha sido reemplazado por la soya. La soya es utilizada ampliamente como fuente de proteína en las dietas humanas y animales, pero posee ciertos factores antinutricionales (tales como los inhibidores de tripsina y 
as well as with gut homeostasis, thus reducing of weight gain. Thereby, it is important to explore the effects of different processing methods on its nutritional quality (4), and consequently on birds health and growth rates.

Though non-thermal treatments may be used to neutralize anti-nutritional factors in soybeans (2), a wide range of heat-treatments are the most commonly used as they promote protein denaturation (4); however excessive heat-treatment may compromise also the nondeleterious protein and amino acid availability in the meal, which is particularly prejudicial on what concerns the essential amino acids and vitamins, even if overheating is avoid (2, $5)$. So, it is important to determine the proper heat-treatment for an adequate formulation of soybean diets.

Autoclaving, extrusion and microwave irradiation have been described as effective methods for reducing deleterious constituents from seed legumes (4). Due to differences in the methods, the success in the inactivation of non-nutritional factors surely differs between these methods, since the degree of protein denaturation depends on the intensity and duration of the thermal treatments and also on the parallel effect of pressure that is used in certain methods such as autoclaving.

The goal for the thermal processing of seed legumes for poultry nutrition is to increase the nutritional value of feed and to maximize the bird performance. To select the appropriate method for these heat procedures it is ought to compare the process outcome in the same conditions, to minimize the side effects of environmental factors on the groups' performances. However, limited research has been conducted in poultry fed soybean based diets in regard to soybean processing on blood parameters of broilers. Therefore, this study aimed to investigate the effect of different heat processing methods on the blood serum parameters in broilers.

\section{MATERIALS AND METHODS}

Study site. This study was conduct in 2011 , in the poultry farm facilities and the Nutrition and Milk Industry Animal Nutrition Laboratory of the Agriculture Faculty of Islamic Azad University,

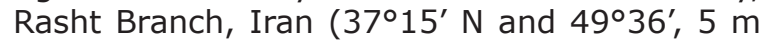
above sea level). The experiments lasted 42 days.

The study was approved by the Scientific Board of the Islamic Azad University, and was conducted lecitinas) que pueden interferir con la digestibilidad de la proteína y su absorción, además del homeostasis de los intestinos, reduciendo así el aumento de peso. Por eso, es importante explorar los efectos de diferentes métodos de procesamiento sobre la calidad nutritiva (4) y en consecuencia la salud de las aves y los índices de crecimiento.

Aunque los tratamientos no térmicos pueden ser usados para neutralizar los factores anti-nutricionales de la soya (2), un amplio rango de tratamientos térmicos son usados con más frecuencia, puesto que promueven la desnaturalización de proteínas (4); sin embargo, el exceso de tratamiento térmico puede adicionalmente comprometer las proteínas que no son nocivas y la disponibilidad de los aminoácidos en el alimento, lo que sería particularmente perjudicial en lo que concierne a los aminoácidos esenciales y vitaminas, aun si se evita sobrecalentamiento (2), 5). Así que es importante determinar el tratamiento térmico apropiado para formular de manera adecuada la dieta de soya.

Para reducir constituyentes nocivos de legumbres de granos, se han descrito como métodos efectivos el autoclave, la extrusión, y la irradiación por micro ondas (4). Debido a diferencias entre estos métodos, el éxito al inactivar los factores no nutricionales difiere entre los métodos, puesto que el grado de desnaturalización de la proteína depende de la intensidad y duración de los tratamientos térmicos y también en los efectos paralelos de presión que se usa en ciertos métodos, como el de autoclave.

El objetivo en el procesamiento térmico de leguminosas de grano, para alimentar aves de corral, es de aumentar el valor nutricional del alimento, y maximizar el rendimiento del ave. Para seleccionar un método apropiado para estos procedimientos térmicos, se debe comparar el resultado de los procesos bajo las mismas condiciones para minimizar los efectos secundarios de los factores ambientales en el rendimiento del grupo. Sin embargo, solo se han hecho investigaciones limitadas en aves sometidas a tratamientos a base de soya en lo que tiene que ver con los parámetros sanguíneos de pollos de engorde. Por ende, este estudio tiene el objetivo de investigar el efecto que tienen diferentes métodos de procesamiento térmico en los parámetros sanguíneos de pollos de engorde.

\section{MATERIALES Y MÉTODOS}

Sitio del estudio. Este estudio se llevó a cabo en 2011 en las instalaciones de la granja avícola y el Laboratorio de la Industria de Nutrición y Leche Nutrición Animal de la Facultad Agropecuario de la Islamic Azad University, Rasht Branch, Iran (37²15’ N y 49³6', 5 msnm). Los experimentos duraron 42 días. 
in respect to the International Guidelines for research involving animals (Directive 2010/63/ EU).

Animals. In this study, 200 male Ross 308 broilers were randomly distributed into 5 treatments with 4 replicates per treatment, in a total of 40 birds per treatment. The experiments started with one-day-old chicks, which were randomly assigned into groups with similar mean body weights, with a starting average weight of $42 \mathrm{~g}$.

The experimental diets were maintained until the age of 42 days, thus covering 3 periods: the starter (1-14 days), the grower (15-35 days) and finisher (36-42 days) periods.

Soybean thermal processing and diets formulation. All thermal treatments were performed at the Nutrition and Milk Industry Laboratory of the Faculty of Agriculture, Islamic Azad University, Rasht Branch. For the heattreatment, portions of $1.5 \mathrm{~kg}$ were placed into the centre of trays and then distributed homogeneously over the tray surface to achieve uniformity during treatment. After the thermal treatments, the meals were allow to cooling in a different tray before being transferred into plastic bags and stored at an adequate temperature $\left(25^{\circ} \mathrm{C}, 60 \%\right.$ humidity).

In this study, the five treatments evaluated and the soybean processing was as follows:

a) Raw soybean meal, originated from the Cerrado region of Brazil, as controls (Ctr group);

b) Soybean meal autoclaved at $121^{\circ} \mathrm{C}$ under 1 Pascal pressure (Iran TebZaeem autoclave 2000), for short or medium length treatment (respectively 20 minutes for Aut 1 , or 30 minutes for Aut2).

C) Soybean meal browned at $120^{\circ} \mathrm{C}$ (20 min; Brn group)-Soybean browning was conducted using Do 636 Memert Oven, UNB400 model, with beans poured into a special aluminium container of $2 \mathrm{~cm}$ height, for achieving an homogeneous temperature for the entire meal. The tray entered the oven when the temperature stabilized at $120^{\circ} \mathrm{C}$ and remained in the oven for $20 \mathrm{~min}$.

d) Micro-waved soybean meal $\left(46^{\circ} \mathrm{C}, 540\right.$ Watt, 7 min; McW group)- Microwave treatment was performed on a household LG microwave, TCR 4284-CC. Before treated in the microwave, soybean was milled, the atmospheric humidity was determined using a psychrometer and the moisture in the sample adjusted to $25 \%$.
El estudio fue aprobado por el Scientific Board of the Islamic Azad University, y se llevó a cabo respetando las Normas Internacionales para investigaciones con animales (Directiva 2010/63/EU).

Animales. Para este estudio, 200 machos de la raza Ross y 308 pollos de engorde fueron distribuidos en 5 grupos de tratamiento y 4 por tratamiento, con un total de 40 aves por tratamiento. Los experimentos empezaron con pollitos de un día que fueron asignados a grupos según el peso corporal medio, con un peso mínimo promedio de $42 \mathrm{~g}$.

Las dietas experimentales se mantuvieron hasta la edad de 42 días, abarcando así 3 periodos: los periodos de iniciador (1-14 días) crecimiento (15-35 días), y finalizador (36-42 días).

Procesamiento térmico de soya y dietas de formulación. Se efectuaron todos los tratamientos térmicos en el Laboratorio de la Industria de Nutrición y Leche de la Facultad de Agropecuaria de la Islamic Azad University, sede Rasht. Para el tratamiento térmico, se colocaron porciones de $1.5 \mathrm{~kg}$ en el centro de bandejas y luego fueron distribuidos de manera homogénea sobre la superficie de la bandeja para alcanzar la uniformidad durante el tratamiento. Después de los tratamientos térmicos, se enfrió la harina en otra bandeja antes de ser transferida a bolsas pasticas y almacenadas bajo a una temperatura adecuada $\left(25^{\circ} \mathrm{C}\right.$, humedad $\left.60 \%\right)$.

En este estudio, los cinco tratamientos que se evaluaron y el procesamiento de soya se llevaron a cabo de la siguiente manera:

a) Harina de soya cruda, de la región Cerrado de Brasil, como grupo de control (grupo Ctr);

b) Harina de soya en autoclave a $121^{\circ} \mathrm{C}$ bajo presión a 1 Pascal (Iran TebZaeem autoclave 2000), por tratamientos de plazo corto o mediano (20 minutos para Aut1, o 30 minutos para Aut2, respectivamente).

c) Harina de soya tostada a $120^{\circ} \mathrm{C}$ (20 min; grupo Brn). Fue tostada utilizando un horno Do 636 Memert, modelo UNB400, con granos vaciados en un envase de $2 \mathrm{~cm}$ de altura para logar una temperatura homogénea para toda la harina. La bandeja fue introducida en el horno cuando la temperatura se estabilizó a $120^{\circ} \mathrm{C}$ y permaneció en el horno por 20 min.

d) Harina de soya en microondas $\left(46^{\circ} \mathrm{C}, 540 \mathrm{~W}, 7\right.$ min; grupo $\mathrm{McW}$ ). El tratamiento microondas fue llevado a cabo en un microonda LG de uso doméstico, TCR 4284-CC. Antes de ser tratado en microondas, el grano fue molido y la humedad atmosférica fue determinada utilizando un psicrómetro, y la humedad en la muestra fue ajustada a $25 \%$. Después, los granos fueron introducidos en microondas dentro de 
Afterwards, the soybeans entered the microwave within $7 \mathrm{~cm}$ diameter Pyrex and treated at 540 watt for $7 \mathrm{~min}$.

The composition of the diets used in this study is presented in table 1 . Soybean was incorporated in all the diets in a fixed proportion of $40 \%$, $35 \%$ and $39.97 \%$ respectively in the starter, the grower and the finisher diets (Table 1 ).

Table 1. Composition of the diets used in this study for the different rearing periods.

\begin{tabular}{lccc}
\hline \multicolumn{1}{c}{ Ingredient (\%) } & Starter & Grower & Finisher \\
\hline Corn & 46.09 & 50.91 & 48.88 \\
Soybean Meal & 40.00 & 35.00 & 39.97 \\
Oil & 4.56 & 5.45 & 7.39 \\
Fish Meal & 3.00 & 3.00 & - \\
Meat Meal & 3.00 & 3.00 & - \\
DL-Methionine & 0.29 & 0.23 & 0.17 \\
L-Lysine*HCL & 0.04 & - & - \\
L-Threonine & 0.03 & - & - \\
Ca22\%P18\% & 0.99 & 0.75 & 1.64 \\
CaCO3 & 0.98 & 0.76 & 1.00 \\
K-Bicarbonate & 0.05 & - & - \\
NaCl & 0.37 & 0.37 & 0.45 \\
KCl & - & 0.03 & - \\
Vitamins \& Minerals Mixture & 0.60 & 0.50 & 0.50 \\
\hline & 100 & 100 & 100 \\
\hline
\end{tabular}

Sampling and blood parameters. Forty birds in each experimental group were weighted at the end of the first week and at the end of the experiment, at the age of 42 days. Moreover, at the end of the feeding trials, one bird from each replicate, in a total of 4 birds for each experimental diet, was randomly selected for blood sampling.

Blood samples ( 1 mL/bird) were collected from the wing veins into tubes for serum separation and rapidly transferred to the laboratory for analysis (within $2 \mathrm{~h}$ of collection). After centrifugation $(3000 \mathrm{~g}$, for $10 \mathrm{~min}$ at room temperature) serum was harvested.

Blood parameters analysed in this study included: glucose (GLU), cholesterol (Chol), triglycerides (TG), very low-density lipoprotein (VLDL), high density lipoprotein (HDL), low density lipoprotein (LDL), HDL/LDL ratios, uric acid (UAc), albumin (Alb), total protein (TP), calcium (Ca) and phosphorus $(P)$. The measurements were performed with commercial kits from Pars Azmoon (Pars Azmoon Co., Tehran, Iran), according to the manufacturer's instructions. GLU was measured by a glucoseoxidase photometric assay (6), while Chol, TG, HDL, LDL and VLDL were determined by enzymatic un envase Pyrex de $7 \mathrm{~cm}$ y tratado a $540 \mathrm{~W}$ por 7 minutos.

La composición de las dietas utilizadas en este estudio se presentó en Tabla 1. Harina de soya fue incorporada en todas las dietas en una proporción establecida de $40 \%, 35 \%$ y $39.97 \%$ respectivamente para las dietas de iniciador, crecimiento y finalizador (Tabla 1).

Muestreo y parámetros sanguíneos. Cuarenta aves de cada grupo experimental fueron pesadas al final de la primera semana y al final del experimento, a la edad de 42 días. Además, al final de los ensayos alimenticios, un ave de cada replicado, un total de 4 aves para cada dieta experimental, fueron escogidas para un muestreo de sangre.

Muestras de sangre ( $1 \mathrm{~mL} / a v e)$ fueron sacadas de las venas de las alas en tubos para separar suero y transferidas de manera rápida (dentro de dos horas de ser extraídas) al laboratorio para análisis. Después de centrifugar (3000 g por $10 \mathrm{~min}$ a temperatura de ambiente) el suero fue analizado.

Los parámetros sanguíneos analizados en este estudio incluyeron: glucosa (GLU), colesterol (Chol) triglicéridos (TG), lipoproteínas de muy baja densidad (VLDL), lipoproteínas de alta densidad (HDL), lipoproteínas de baja densidad (LDL), índice HDL/LDL, ácido úrico (UAc), albumina (Alb), proteínas totales (TP), calcio (Ca) y fosforo (P). Las medidas fueron tomadas con kits comerciales de Pars Azmoon (Pars Azmoon Co., Teherán, Irán), según las instrucciones del fabricante. Se midió la GLU por medio de un ensayo fotométrico de glucosa-oxidase (6), mientras que se determinó los valores de Chol, TG, HDL, LDL y VLDL por ensayos enzimáticos CHOD-PAP, la reacción siendo revelada por la reacción con aminoantipyrin (6). Se determinó el Alb basado en el método de bromocresol verde (6), mientras el UAc fue determinado por los métodos enzimáticos utilizando el método uricaseTOOS (6) y se ensayó el TP usando el método Biuret (6). Se estimó el calcio del complejo formado de kersulphetalina (6), y el fosforo fue determinado por el método fotométrico (6) por medio de una prueba UV.

Analisis de datos. Datos complicados durante los ensayos experimentales se organizaron en hojas de Excel y los análisis estadísticos se hicieron con SAS ${ }^{\circledR}$ 8.0 (7). Para el análisis estadístico el promedio de los resultados replicados fue considerado con una unidad experimental. Datos recolectados en este experimento fueron sujetos a análisis de varianza utilizando procedimientos GLM en una forma completamente aleatoria; antes de practicar el análisis de varianza, la prueba de normalidad se llevó a cabo. La comparación promedio entre grupos y replicados se logró por medio de la prueba Tukey multi-dominio a un 5\% de probabilidad. 
CHOD-PAP assays, the reaction being revealed by reaction with aminoantipyrin (6). Alb was determined based on the bromocresol green method (6), whilst the UAc was determined by enzymatic methods using the uricase-TOOS method (6) and TP was assayed by the Biuret method (6). Calcium was estimated from formed kersulphetaline complex (6), and phosphorus was determined by photometric method (6) by means of UV test.

Data analysis. Data gathered during the experimental trials were organised in Excel data sheets and the statistical analysis performed with $\mathrm{SAS}^{\circledR} 8.0$ (7). For statistical analysis the mean of replicate results was considered as the experimental unit. Data gathered in this experiment were subjected to analysis of variance using GLM procedures in a completely randomized design; before performing the analysis of variance, normality test was carried out. Mean comparisons between groups and replicates was achieved by the multi-domain Tukey test at $5 \%$ probability.

\section{RESULTS}

Data obtained in this study are summarized in tables 2 and 3. At the end of the experimental period, the soybean thermal processing influenced the final body weight $(p=0.012)$. By week 1 , the groups presenting the highest body weights were the Aut1 and McW ( $p=0.017$ and $p=0.002$, respectively), whilst the Aut2 group tend to present lower weight than all others heat-treated groups $(p=0.015)$. All treatment Aut2, Brn, and McW groups presented higher body weight than controls at the end of the study (Table 2), with Aut2 and McW groups being those with the highest values at the end of the trials (respectively, $p \leq 0.000$ and $p=0.000)$, just fallowed by Brn group $(p=0.006)$.

Soybean treatment did not significantly affect glucose concentration in blood $(p=0.687$; Table 3 ). The GLu concentrations in serum were similar between groups Aut1, McW and control, whilst an increase was noticed in Aut2 and Brn groups (Figure 1).

Serum Chol levels did not vary between groups $(p=0.158)$, thought they were generally lower than control group. Still, though no differences were found in absolute serum values between soybean treatment groups (Table 3), a tendency was detected in Aut2 group to present the lowest serum values for Chol ( $p=0.0523$; Figure 1$)$.

Similarly, TG serum levels did not differ among the dietary groups $(p=0.589)$. Nevertheless, lower serum levels were observed in birds fed

\section{RESULTADOS}

Datos obtenidos en este ensayo se resumen en tablas 2 y 3 . Al final del periodo experimental, el tratamiento térmico de la soya afectó el peso corporal final $(p=0.012)$. Para la semana 1 , los grupos que presentaron los pesos corporales más altos fueron Aut1 y McW ( $p=0.017$ y $p=0.002$, respectivamente), mientras que el grupo Aut2 presento peso corporal más bajo que todos los demás grupos de tratamiento térmico $(p=0.015)$. Todos los grupos de tratamiento Aut2, Brn, y McW presentaron peso corporal más alto que los grupos de control para el final de los ensayos (Tabla 2), con los grupos Aut2 y McW siendo los que tenían los valores más altos para el final de los ensayos (respectivamente, $\mathrm{p} \leq 0.000$ y $\mathrm{p}=0.000$ ), seguido por el grupo Brn $(p=0.006)$.

El tratamiento con soya no afectó de manera significativa la concentración de glucosa en la sangre ( $p=0.687 ;$ Tabla 3). Las concentraciones de GLu en suero fueron similares entre los grupos Aut1, McW y control, mientras se notó aumentó en los grupos Aut2 y Brn (Figura 1).

Los niveles Chol en suero no variaron entre los grupos $(p=0.158)$, aunque fueron más bajos en general que el grupo de control. Aunque no se encontraron diferencias en los valores absolutos de suero entre grupos de tratamiento con soya (Tabla 3), se detectó una tendencia en el grupo Aut2 a presentar los valores más bajos en suero para Chol ( $\mathrm{p}=0.0523$; Figura 1$)$.

Asimismo, los niveles TG en suero no variaron entre los grupos de tratamiento $(p=0.589)$. Sin embargo, se vieron niveles de suero más bajos en aves alimentadas con alimento de autoclave e irradiadas con micro ondas (Tabla 3); Brn el grupo que mostró los valores más cercanos en comparación con Ctr (Figura 1).

El tratamiento térmico con soya afectó de manera significativa las concentraciones $\mathrm{HDL}$ en el suero de pollos de engorde $(p=0.043)$, siendo más baja en los grupos tratados cuando se comparó con el control

Table 2. Comparison of the total body weight (in grams) of chicks at $1^{\text {st }}$ week and by the end of the feeding trials, at 42 days.

\begin{tabular}{ccc}
\hline Treatments $^{* *}$ & Day $\mathbf{7}$ & Day 42 \\
\hline Ctr & $126.50^{\mathrm{c}} \pm 1.24$ & $2423.57^{\mathrm{b}} \pm 15.43$ \\
Aut1 & $132.88^{\mathrm{a}} \pm 1.74$ & $2546.50^{\mathrm{ab}} \pm 91.96$ \\
Aut2 & $128.63^{\mathrm{ab}} \pm 1.66$ & $2676.70^{\mathrm{a}} \pm 32.09$ \\
Brn & $129.00^{\mathrm{ab}} \pm 2.79$ & $2595.45^{\mathrm{a}} \pm 27.42$ \\
McW & $132.63^{\mathrm{a}} \pm 0.55$ & $2613.82^{\mathrm{a}} \pm 28.82$ \\
P-value & 0.0174 & 0.0121 \\
\hline
\end{tabular}

${ }^{*}$ In each column, the averages with different letters indicate significant differences $(\mathrm{P}<0.05)$ between treatments.

${ }^{* *}$ Ctr: raw soybean (controls), Aut1: autoclaved for a short $\left(121^{\circ} \mathrm{C}, 20 \mathrm{~min}\right)$ soybean meal; Aut2: autoclaved for a medium length period $\left(121^{\circ} \mathrm{C}, 30 \mathrm{~min}\right)$ soybean meal; Brn: browned soybean meal $\left(120^{\circ} \mathrm{C}, 20 \mathrm{~min} ; \mathrm{Brn}\right.$ group); McW: micro-waved soybean meal $\left(46^{\circ} \mathrm{C}, 540 \mathrm{Watt}, 7 \mathrm{~min}\right.$; McW group). 
Table 3. Comparison of blood serum metabolites (mean \pm SEM) at day 42 in the blood of broilers from the five studied treatments*

\begin{tabular}{|c|c|c|c|c|c|c|c|}
\hline & \multicolumn{7}{|c|}{ Treatments $^{* *}$} \\
\hline & Ctr & Aut1 & Aut2 & Brn & McW & CV (\%) & P-value \\
\hline Glu [mg/dl] & $265.500 \pm 4.093$ & $262.250 \pm 6.909$ & $273.500 \pm 10.822$ & $281.750 \pm 16.800$ & $269.500 \pm 6.035$ & 7.400 & 0.687 \\
\hline Chol [mg/dl] & $115.000 \pm 4.664$ & $102.500 \pm 5.809$ & $98.250 \pm 5.721$ & $100.000 \pm 5.788$ & $111.750 \pm 5.282$ & 10.360 & 0.158 \\
\hline $\mathrm{TG}[\mathrm{mg} / \mathrm{dl}]$ & $88.500 \pm 5.838$ & $72.250 \pm 12.566$ & $74.000 \pm 6.272$ & $83.500 \pm 6.764$ & $74.750 \pm 8.076$ & 21.050 & 0.589 \\
\hline VLDL $[\mathrm{mg} / \mathrm{dl}]$ & $17.700 \pm 1.168$ & $14.450 \pm 2.513$ & $14.950 \pm 1.181$ & $16.700 \pm 1.252$ & $14.950 \pm 1.615$ & 20.880 & 0.598 \\
\hline $\mathrm{HDL}[\mathrm{mg} / \mathrm{dl}]$ & $68.000 \pm 2.041^{a}$ & $62.750 \pm 2.839^{b}$ & $59.000 \pm 2.739^{b}$ & $58.750 \pm 2.097^{b}$ & $66.750 \pm 2.097^{a}$ & 7.580 & 0.043 \\
\hline $\mathrm{LDL}[\mathrm{mg} / \mathrm{dl}]$ & $29.750 \pm 1.702$ & $31.250 \pm 3.326$ & $26.000 \pm 1.780$ & $27.750 \pm 2.750$ & $29.250 \pm 1.652$ & 16.260 & 0.584 \\
\hline HDL/LDL & $2.297 \pm 0.107$ & $2.052 \pm 0.197$ & $2.277 \pm 0.083$ & $2.162 \pm 0.177$ & $2.272 \pm 0.081$ & 12.400 & 0.692 \\
\hline $\mathrm{UAC}[\mathrm{mg} / \mathrm{dl}]$ & $6.950 \pm 0.762$ & $8.250 \pm 0.835$ & $10.525 \pm 1.694$ & $9.100 \pm 1.207$ & $10.450 \pm 1.502$ & 27.690 & 0.263 \\
\hline Alb $[\mathrm{g} / \mathrm{dl}]$ & $1.130 \pm 0.063^{b}$ & $1.400 \pm 0.071^{a}$ & $1.370 \pm 0.048^{a}$ & $1.270 \pm 0.025^{a b}$ & $1.300 \pm 0.041 \mathrm{ab}$ & 8.000 & 0.016 \\
\hline $\operatorname{TP}[\mathrm{g} / \mathrm{dl}]$ & $3.025 \pm 0.103^{b}$ & $3.625 \pm 0.197^{a}$ & $3.550 \pm 0.119^{\mathrm{ab}}$ & $3.375 \pm 0.103 a b$ & $3.475 \pm 0.125^{\mathrm{ab}}$ & 7.860 & 0.050 \\
\hline $\mathrm{P}[\mathrm{mg} / \mathrm{dl}]$ & $5.425 \pm 0.131$ & $5.325 \pm 0.228$ & $5.275 \pm 0.085$ & $5.175 \pm 0.149$ & $5.350 \pm 0.050$ & 5.000 & 0.762 \\
\hline $\mathrm{Ca}[\mathrm{mg} / \mathrm{dl}]$ & $9.820 \pm 0.531$ & $10.620 \pm 0.303$ & $10.270 \pm 0.335$ & $10.370 \pm 0.629$ & $10.400 \pm 0.234$ & 8.400 & 0.789 \\
\hline
\end{tabular}

${ }^{*}$ In each row, the averages with different letters indicate significant differences $(P<0.05)$ between treatments.

${ }^{* *} \mathrm{Ctr}$ : raw soybean (controls), Aut1: autoclaved for a short $\left(121^{\circ} \mathrm{C}, 20 \mathrm{~min}\right)$ soybean meal; Aut2: autoclaved for a medium length period (121 $1^{\circ} \mathrm{C}, 30$ min) soybean meal; Brn: browned soybean meal $\left(120^{\circ} \mathrm{C}, 20 \mathrm{~min}\right.$; Brn group); McW: micro-waved soybean meal (46 ${ }^{\circ} \mathrm{C}, 540 \mathrm{Watt}, 7 \mathrm{~min}$; McW group).

SEM: Standard error of the mean. CV :Coefficient of variation

with autoclaved and microwave irradiated meals (Table 3); Brn was the group that showed the closest values compared to Ctr (Figure 1).

Soybean thermal treatment significantly affected the HDL concentrations in broilers' serum $(p=0.043)$, being lower in all treated groups when compared to control (Table 3). HDL levels did not differ between groups Ctr and McW (Figure 1). Values for blood concentrations of HDL were particularly lower in groups Aut1, Aut2 and Brn and statistically different from the other groups ( $p<0.01$; Figure 1$)$.

Small and not significant changes were observed in the LDL absolute values between birds feed with differently treated soybean meals (Table 3 ). LDL serum values were lower than controls in all the treatment groups except Aut1 that showed a small increase in serum LDL concentrations (Figure 1). Still, the differences were voided of significance $(p=0.584)$.

The HDL/LDL ratio was showed small, nonsignificant changes amongst all treatment groups and the controls $(p=0.692)$, the main decrease being presented by Aut1 group (Table 3 ). The $\mathrm{HDL} / \mathrm{LDL}$ ratio was lower than the control in all treatments despite no significant different were evident.

Soybean thermal treatment did not influence VLDL levels in the blood serum $(p=0.598)$, despite that all treated groups presented lower blood concentrations than the control (Table 3; Figure 1). The largest changes were observed in the Aut1, Aut2 and McW groups.

Serum levels for UAC were raised in all treated groups compared with controls (Table 3 ); still no statistical differences were found between groups $(p=0.263)$. Yet, a tendency was noticed to
(Tabla 3). Los niveles HDL no difirieron entre los grupos Ctr y McW (Figura 1). Los valores de concentraciones sanguíneos de HDL fueron particularmente más bajos en los grupos Aut, Aut2 y Brn y diferentes de manera estadística de los otros grupos ( $p<0.01 ;$ Figura 1$)$.

Cambios pequeños e insignificantes se observaron en los valores absolutos de LDL, entre aves alimentadas con harinas de soya tratadas de manera diferentes (Tabla 3). Los valores LDL de suero fueron más bajos que los controles en todos los grupos de tratamiento con la excepción de Aut1, que mostró un pequeño aumento en concentraciones LDL en suero (Figura 1). Sin embargo, las diferencias no fueron significativas $(p=0.584)$.

La proporción HDL/LDL mostró cambios pequeños y no significantes en comparación con todos los grupos de tratamiento y los controles ( $p=0.692)$, el descenso principal siendo presentado por el grupo Aut1 (Tabla 3). La proporción HDL/LDL fue más bajo que el control en todos los tratamientos a pesar de que no hubo diferencias significativas.

El tratamiento térmico de soya no afectó los niveles VLDL en el suero sanguíneo $(p=0.598)$, a pesar del hecho de que todos los grupos tratados presentaron concentraciones en la sangre más bajos que en el control (Tabla 3, Figura 1). Los cambios más grandes fueron observados en los grupos Aut1, Aut2 y McW.

Los niveles de suero de UAc se elevaron en todos los grupos tratados en comparación con los grupos de control (Tabla 3); sin embargo, no había diferencias estadísticas entre los grupos $(p=0.263)$. Aún, se notó una tendencia a registrar concentraciones más altas de UAc en pollos de engorde de los grupos Aut2 y McW $(p=0.091$ y $p=0.071$, respectivamente; Figura 1$)$.

El Tratamiento de calor durante el procesamiento de harina de soya mostró tener un impacto importante 

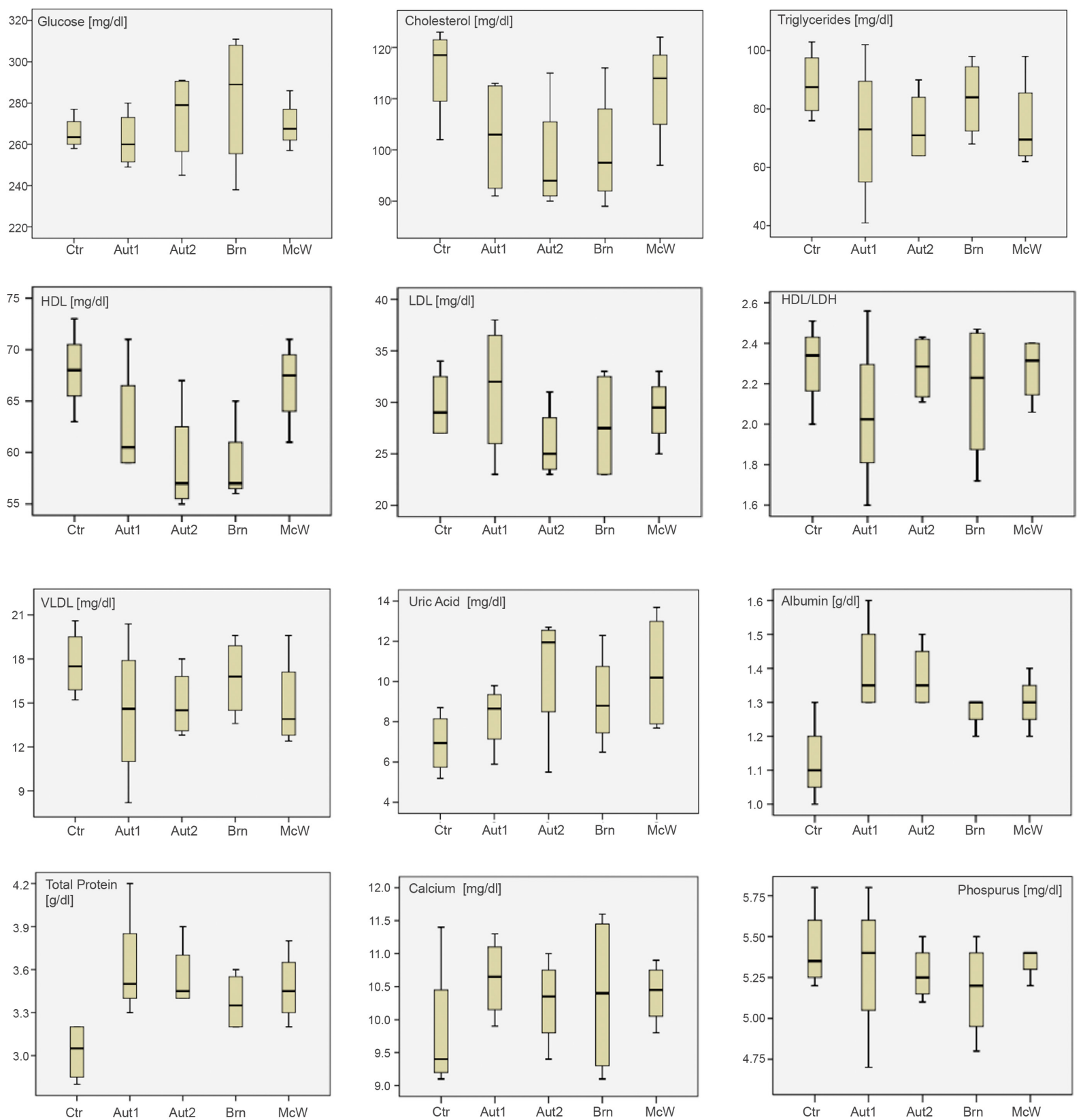

Figure 1. Box-plot representation for effects of thermal soybean treatment in blood serum metabolites concentration at day 42 in male Ross 308 broilers.

record higher UAc concentrations in broilers from groups Aut2 and McW ( $p=0.091$ and $p=0.071$, respectively; Figure 1$)$.

Heat-treatment during soybean meal processing showed to have an important impact on the blood albumin levels in broilers $(p=0.016)$. Autoclaving of soybean meals was the thermal treatment with largest differences from controls $(p=0.022$ and $p=0.016$, respectively for groups Aut 1 and Aut2), in comparison to Brn and McW groups that showed moderate changes towards controls en los niveles de albumina en la sangre de pollos de engorde $(p=0.016)$. El tratamiento termal por autoclave de la harina de soya mostró las diferencias más grandes en comparación con los grupos de control $(p=0.022$ y $p=0.016$, respectivamente para grupos Aut1 y Aut2), en comparación con los grupos Brn y McW que mostraron cambios moderados hacía los controles $(p=0.073$ y $p=0.054$, respectivamente; Figura 1$)$. Brevemente, las diferencias en valores promedios de albumina en la sangre fueron significativos para Aut1 y Aut2 cuando se compararon con Crt solamente, y no difirieron entre tratamientos térmicos. 
$(p=0.073$ and $p=0.054$, respectively; Figure $1)$. Briefly, differences in mean values of blood albumin were significant for Aut1 and Aut2, when compared with Crt, only, and they do not differ between thermal treatments.

Blood concentrations of total proteins significantly differed among all groups $(p=0.050)$, with major differences found between broilers with treated meals and controls (respectively $p=0.027$, $p=0.010, p=0.043, p=0.024$ for groups Aut1, Aut2, Brn and McW). Treatment groups showed higher protein serum levels than controls (Table 3; Figure 1), with major differences found in Aut1 group, whilst the mean values for the remainder groups (Aut2, Brn and McW) tend to be closer to controls $(p=0.090)$. Briefly, the only difference observed is related with Aut1, and this treatment only differ from Crt. Total protein in serum do not varied with the other treatments

Thermal treatments did not influence the serum concentrations of Ca $(p=0.789)$ or $P(p=0.762)$ (Figure 1). Still, Ca average concentrations were higher for soybean treated meals than in controls (Table 3). There are no significant differences among the groups on respect to $\mathrm{P}$ (Table 3 ).

\section{DISCUSSION}

Inclusion of soybean in poultry diet demands for a balanced pre-treatment to neutralize the anti-nutritional factors to an acceptable levels without compromising the availability of essential amino acids, and therefore the nutritional quality of the diet. An adequate control of both the temperature and processing time is crucial to achieve such balance and to allow the production of an acceptable carcass both in weight and in composition.

In the present experiment we compared the effect of different heat or heat and pressure treatments on the blood serum metabolites of broilers feed soybean-based diets. Previously, it was showed that feeding birds with raw soybean meal the chicks revealed very poor feed utilization (8). In general, in the study presented herein, none of the treatments compromised nutrient availability when compared to the control (raw soybean), estimated from the body weight at the end of the experiment. Similar findings were reported in the literature for soybean submitted to different extrusion temperatures or dietary inclusion rate of wet EFFSB (extruded full-fat soybean) in meal (8).

There was a distinct disadvantage of feeding raw soybean meal on body weight in this study, so
Las concentraciones de proteínas totales en la sangre difieren de manera significativa entre todos los grupos $(p=0.050)$ con diferencias grandes encontrados entre pollos de engorde con harinas y controles tratados (respectivamente $p=0.027, p=0.010, p=0.043$, $\mathrm{p}=0.024$ para los grupos Aut1, Aut2, Brn y McW). Los grupos de tratamiento mostraron niveles más altos de proteína en suero que los grupos de control (Tabla 3, Figura 1), con diferencias importantes encontradas en el grupo Aut1, mientras que los valores medios para los otros grupos (Aut2, Brn y McW) tienden a acercarse más a los grupos de control $(p=0.090)$. Brevemente, la única diferencia observada se vio con Aut1, y este tratamiento solamente difiere de Crt. Proteínas totales en suero no variaron con los otros tratamientos.

Los tratamientos térmicos no influenciaron las concentraciones en suero de Ca $(p=0.789)$ o $P$ $(p=0.762)$ (Figura 1). Sin embargo, las concentraciones promedios para Ca fueron más altos para harinas de soya tratadas que en los grupos de control (Tabla 3). No hay diferencias significativas entre los grupos con respeto a $\mathrm{P}$ (Tabla 3).

\section{DISCUSIÓN}

Incluir soya en la dieta de aves de corral, requiere un equilibrado tratamiento previo, para neutralizar los factores anti-nutricionales a niveles aceptables, sin comprometer la disponibilidad de los aminoácidos esenciales, y por ende la calidad nutricional de la dieta. Un control adecuado tanto de la temperatura y el tiempo de procesado es crucial para lograr tal balance y permitir la producción de un cadáver aceptable tanto en peso como composición.

En el presente experimento se compararon los efectos de diferentes tratamientos de calor, o calor y presión en los metabolitos de suero sanguíneo en pollos de engorde que fueron alimentados con dietas basadas en la soya. Previamente se mostró que al alimentar las aves con harina de soya cruda, estas mostraron una pobre utilización del alimento (8). En general en este estudio, ninguno de los tratamientos comprometió la disponibilidad de los nutrientes comparados con el grupo de control (soya cruda), estimado según el peso corporal al final del experimento. Se registraron hallazgos similares en la literatura referente a la soya que ha sido sometido a diferentes temperaturas de extrusión o la tasa de inclusión de EFFSB húmedo (soya de grasa completa extruida) en harina (8).

En este estudio hubo una marcada desventaja en el peso corporal al alimentar las aves con harina de soya cruda, así que el peso corporal de las aves en los tratamientos Aut2, Brn y McW a los 42 días de edad fue significantemente más alto que el de las aves de control. Además, puede ser que algunos de los 
body weight of Aut2, Brn, and McW treatment birds at 42 nd day of age was higher than control birds significantly. Also, some of the thermal treatments (Aut1) may not successfully destroy deleterious compounds in soybean. The body weight at 42 days in chickens fed with raw soybean or autoclaved soybean for $20 \mathrm{~min}$ was lower than those of birds fed with meals submitted to autoclaving for 30 min or microwave treated, although Aut1 treatment had not significant differences from the other treatments. The lowest body weight was observed in Aut1 and Brn. Therefore, the reduction of the birds' weight at the end of the trials suggests that a short (20 min) autoclaving or browning treatments were insufficient to adequately neutralise antinutritional substances found in raw soybean.

The differences found among body weights for the different thermal processing of the meals were not so clearly expressed by the end of the first week in birds, but it might be possible that differences were related to differences in growth rates and on the energy demands between the two periods (day 7 and day 42) for maintenance and meat production. Another explanation could be that ingestion of soybean meal submitted to different thermal treatments induces differences in intestinal microbial flora, thus interfering with the absorption ability of ingesta within the digestive tract. Still, available data from Nahavandinejad et al (9) showed that no differences were found among heat treatments on regards to total bacteria, E. coli and lactobacillus content in the cecum, although the lactic acid bacteria population increased significantly in birds fed heat-treated meals.

The combination of the temperature, pressure and length of the autoclaving treatment seemed not to be detrimental to the production of an acceptable body weight at the end of rearing (9).

In heat-treated soybean meal, particular attention must be paid to the protein content and protein quality in the final product, as thermal treatments may change the amino acid composition of diets, most importantly on the essential amino acids. Changes in protein or amino acids availability and additionally the presence of isoflavones may affect cholesterol and energetic metabolism (10). It is generally accepted that, in birds, manipulation of diets may originate modification of the profiles of metabolic hormones and metabolites in blood, alike it happens with variations due to the strain, age or sex. In the present study, blood indicators for energy, protein or lipid metabolism showed small variations amongst groups. tratamientos térmicos (Aut1) no destruyen con éxito los componentes nocivos de la soya. El peso corporal a los 42 días en pollos alimentados con soya cruda o soya autoclave por 20 min fue más bajo que el de aves alimentados con harinas sometidas a autoclave por 30 min o tratada con micro onda, aunque el tratamiento de Aut1 no tenían una diferencia significativa con los otros tratamientos. El peso corporal más bajo se observó en Aut1 y Brn. Por eso, la disminución del peso de las aves al final de los ensayos sugiere que un tratamiento corto (20 min) de autoclave o tostar no fueron suficientes para neutralizar de manera adecuada las sustancias anti-nutricionales presente en soya cruda.

Las diferencias entre pesos corporales en los diferentes tratamientos térmicos del alimento no fueron claramente expresadas al final de la primera semana en las aves, pero puede ser posible que fueron relacionadas a diferencias en las tasas de crecimiento o en la demanda de energía entre los dos periodos (día 7 y día 42) para mantenimiento y producción de carne. Otra razón podría ser que la ingesta de harina de soya bajo otros tratamientos térmicos provoca diferencias en la flora intestinal microbio, y por ende interfiere con la capacidad de absorber del aparato digestivo. Todavía, data disponible de Nahavandinejad et al (9) mostró que no se encontraron diferencias entre tratamientos térmicos referentes al contenido de bacteria total, E.coli y lactobacilos en el ciego, aunque la población de bacteria ácido láctico aumento de manera significante en aves alimentados con harina con tratamiento térmico.

La combinación de temperatura, presión y duración del tratamiento autoclave pareció no ser nocivo a la producción de un peso corporal aceptable al final de la cría (9).

En harina de soya con tratamiento térmico, hay que prestar atención particular al contenido de proteína y la calidad de la proteína en el producto final, puesto que tratamientos térmicos pueden variar la composición de aminoácidos de la dieta, especialmente de los aminoácidos esenciales. Los cambios la disponibilidad de proteína o aminoácidos y adicionalmente la presencia de isoflavonas pueden afectar el colesterol y el metabolismo energético (10). Es generalmente aceptado que en aves, manipular la dieta puede originar la modificación de perfiles de hormones metabólicas y metabolitos sanguíneos, y puede suceder con variaciones debido a la raza, edad o sexo. En este estudio, los indicadores sanguíneos para energía, proteína o metabolismo de lípidos mostraron variaciones pequeñas entre los grupos.

En la data presentada en este estudio, no se encontraron diferencias en los valores GLU en circulación entre los grupos de tratamiento o los grupos de control. Sin embargo, un aumento en 
In data presented herein, no statistical differences were found in GLU circulating values between the treatment groups or towards the controls. However, an increased in absolute concentrations were found in birds from groups Aut2, Brn and in a lesser extent also in McW. Thought GLU levels are maintained within strict values in circulation due to a finely tuned control mechanism, these may vary with the meal carbohydrate content, the genetic lines, sex and age, stress or the husbandry conditions. Still, it is now accepted that such variations are not consistently associated with changes in body weight. Glucose is an important cellular source for energy and serves as metabolic substrate. The higher absolute values in blood GLU were found in the groups presenting heavier body weights. Nevertheless, this slight increase indirectly suggests that for the groups Aut2, Brn and McW, the thermal treatment of meals did not disturbed nutrient absorption or compromised liver glycogenolysis, in which case a decrease in GLU levels would be expected (11).

Lipid metabolites in blood are strongly associated to the energy metabolism (12). In general, elevated circulating lipids levels indicate enhanced de novo lipolysis, while low lipid profile in blood reflects an increased rate of amino acid transportation and enhanced lipid metabolism with consequent decreased in fat deposition (13). In the present study, the analysis of the lipid profile suggests an overall decrease in lipid availability in the blood of birds feed heat-treated meals.

The main changes were recorded for Chol and HDL; still, significant differences among groups were only found for HDL concentrations in blood. Moreover, the circulating values for both lipid metabolites were markedly lower than in controls compared with similar groups of Ross 308 broilers, reared under analogous management at the same station, also feed a soybean-based diet (14). This difference may be related to differences in soybean concentration of anti-nutritional factors, which may differ with the variety (15), the origin (16) or the maturation of the crops (17), or on the absorption or metabolism of cholesterol, which might be either associated to changes in the intestinal environment or to the meal content in isoflavones and fibre. Still, an increased in isoflavones would expectably be associated with an increase in total blood lipid levels, which was not the case in this experiment.

On the other hand, older studies reported that changes in nutrient availability in animals fed soybean-based meals might be related to a las concentraciones absolutas se encontró en aves de grupos Aut2, Brn y a un grado menor también en McW. Aunque los niveles GLU se mantuvieron dentro de valores estrictos en circulación debido a un cuidadosamente ajustado mecanismo de control, estos pueden variar con el contenido de carbohidratos de la harina, las líneas genéticas, sexo y edad, estrés o condiciones agrícolas. Sin embargo, es aceptado ahora que tales variaciones no son asociadas de manera consistente con cambios en peso corporal. La glucosa es una fuente importante de energía a nivel celular y sirve como substrato metabólico. Los valores absolutos más altos en la GLU sanguíneo se encontraron en los grupos presentando pesos corporales más altos. Sin embargo, este leve aumento sugiere de manera indirecta que para los grupos Aut2, Brn y McW, el tratamiento térmico de harina no afectó la absorción de nutrientes ni comprometió la glicogenolisis del hígado, puesto que en tal caso se esperaría ver un descenso en los niveles GLU (11).

Los metabolitos lípidos sanguíneos están estrechamente asociados con el metabolismo energético (12). En general, niveles lípidos en circulación elevados indican un novo lipolisis acentuado, mientras que perfiles lipídicos bajos en la sangre reflejan una tasa aumentada de transporte de aminoácidos y un metabolismo lipídico acentuado con la consecuente baja en depósitos grasos (13). En este estudio, el análisis del perfil lípido sugiere un descenso general en disponibilidad lipídica en la sangre de aves alimentadas con harina con tratamiento térmico.

Los cambios principales fueron registrados para Chol y HDL; sin embargo, diferencias significativas entre grupos se encontraron solo para concentraciones de HDL en la sangre. Además, los valores en circulación para los metabolitos lipídicos fueron significativamente más bajos que en los grupos de control en comparación con grupos similares de pollos de engorde de raza Ross 308, criados bajo un manejo análogo en la misma estación, y también alimentados con una dieta de soya (14). Esta diferencia puede estar relacionada a diferencias en la concentración de soya de factores anti-nutricionales, que pueden variar con el tipo (15), origen (16) o maduración de los cultivos (17), o en la absorción o metabolismo del colesterol, que puede ser asociado o a cambios en el ambiente intestinal o al contenido de isoflavonas y fibra en la harina. Aún, un aumento en isoflavonas sería asociado a un aumento de niveles lipídicos totales en la sangre, lo que no fue el caso en este experimento.

Por otro lado, estudios más antiguos reportaron que cambios en la disponibilidad de los nutrientes en animales alimentados con harina de soya puede estar relacionados con una reducción en la digestibilidad de grasa debido al aumento de excreción de ácidos biliares. Los valores absolutos para colesterol total bajaban en todos los grupos de tratamiento en 
reduction in fat digestibility due to increased excretion of bile acids. The absolute values for total cholesterol were decreased in all the treatment groups compared to control, particularly in Aut2 and Brn group. Contrasting, blood triglycerides concentrations in blood, though decreased in comparison with controls, were more alike among groups of heat-treated meals. The Brn group presented closer values to the controls for blood TG. Triglycerides decreased values in bloodstream may suggest a decreased in the intensity in lipid metabolism and transport (12). Triglycerides are the most important source of fatty acids for fat accumulation (18), and its levels in blood correlated well with body fat. Thus, its decreased levels in blood suggest that fat deposition may be delayed in animals feed with treated soybean meals, in particular for the groups feed with autoclaved and microwaved meals. The major source for TG variations is the food or GLU conversion (11). However, a clear relation between the blood GLU levels and those for TG were not established in the present work.

As previously said, HDL concentrations in blood encompassed the lower Chol circulating levels, as naturally expected since HDL carries $70 \%$ of total cholesterol in birds (19). In the present experiment, HDL/Chol ratios were relatively similar among the groups fed soybean treated diets and the control; the content of HDL fraction varied from 57 to $61 \%$ of the total cholesterol. Still, a non-significant reduction in the HDL concentrations in blood was found in birds fed autoclaved, browned and micro-waved meals. Additionally, HDL concentrations in all the groups were below those reported by Jahanpour et al. (14) in their Ctr group, using similar chicks and environmental conditions. Being a cholesterol carrier, lower values for HDL reflect the reduction in cholesterol availability for lipogenesis in liver (19), may account for a decrease of fat deposition in carcasses. The diet is an important source of variation for HDL concentrations in blood. Thus it is possible that heat-treatment in soybean based meals might interfere either with the absorption of fat and cholesterol or with lipid metabolism.

LDL levels in bloodstream are relatively constant in birds and reflect the availability of cholesterol and triglycerides for tissue metabolism. In this experiment, despite the absence of differences between control and the meal treated groups an increased absolute value for circulating LDL was found in Aut1 group, just followed by Crt group, opposing to the Aut2 group, which showed the lowest levels.

VLDL is usually envisaged as a good indicator for fat deposition in broilers (8). Synthesised in the comparación con el grupo control, particularmente en los grupos Aut2 y Brn. En contraste, las concentraciones de triglicéridos en la sangre, aunque disminuyeron en comparación con los grupos de control, fueron más parecidos entre grupos de harinas con tratamiento térmico. El grupo Brn presentó valores más cercanos a los grupos de control para TG sanguíneo. Los valores reducidos de triglicéridos en el torrente sanguíneo pueden sugerir una reducción en la intensidad de metabolismo y transporte de lípidos (12). Los triglicéridos son la fuente más importante de ácidos grasos para acumulación de grasa (18), y sus niveles en la sangre correlacionan bien con grasa corporal. Por ende, los niveles reducidos en la sangre sugieren que la deposición de grasa puede demorar en animales alimentados con harina tratada, en particular para los grupos alimentados con harina tratada con autoclave y micro ondas. Una fuente importante de variaciones TG es la comida o la conversión GLU (11). Sin embargo, una relación clara entre los niveles sanguíneos de GLU y los para TG no fueron establecidos en este estudio.

Como expresado anteriormente, las concentraciones de HDL en la sangre encerraron los niveles más bajos de Chol en circulación, según lo esperado puesto que HDL transporta el $70 \%$ del colesterol total en las aves (19). En este experimento, los índices fueron relativamente similares entre los grupos alimentados con harina de soya y el grupo de control; el contenido de fracciones HDL varió entre 57 a $61 \%$ del colesterol total. Sin embargo, una reducción no significante en las concentraciones HDL en la sangre se encontró en aves alimentados con harinas autoclave, tostada o en micro onda. Adicionalmente, las concentraciones HDL in todos los grupos fueron por debajo los reportados por Jahanpour et al. (14) en su grupo Ctr, usando pollitos y condiciones ambientales similares. Siendo un transportador de colesterol, los valores más bajos de HDL reflejen la reducción de la disponibilidad de colesterol para la lipogenesis en el hígado (19), y puede explicar la reducción de grasa depositada en los cadáveres. La dieta es una importante fuente de variación para concentraciones HDL en la sangre. Por eso es posible que el tratamiento térmico en harina de soya puede interferir o con la absorción de grasa y colesterol o con el metabolismo lipídico.

Los niveles LDL en la sangre son relativamente constantes en aves y reflejan la disponibilidad de colesterol y triglicéridos para el metabolismo de tejido. En este experimento, a pesar de la ausencia de diferencias entre el grupo de control y el grupo con harina con tratamiento, un valor absoluto aumentado se encontró en LDL en circulación se encontró entre el grupo Aut1, seguido por el grupo Crt, en oposición al grupo Aut2, que mostró los niveles más bajos.

La VLDL normalmente es un buen indicador de deposición de grasa en pollos de engorde (8). Procesado en el hígado, es un transportador principal 
liver, this is the main transporter of endogenous fat and its amount correlates well with ability for fat deposition $(12,19)$. In the present work, though no differences were found between soybean treatments, lower absolute values were found in autoclaved and microwave irradiated meals compared to those browned. Further, VLDL concentrations in bloodstream were lower than those reported in controls from another study developed in similar environmental and dietetic conditions (14). Decreased VLDL is associated with a decrease in hepatic expression and activity of lipogenic enzymes provoking an alteration in lipids metabolism in the liver and reducing de novo fatty acid synthesis (19).

VLDL concentrations in plasma and HDL/LDL ratios obtained herein are suggestive of a limitative availability of lipids for abdominal fat deposition in all the groups, including control. This in fact is indirectly support by the increases recorded in the chicks' body weight, in particular those with heat-treated meals, since decreased lipid profile in blood has been associated with increased weight of the breast muscle and decreased abdominal fat content (20).

All the metabolites generally used as markers for the protein metabolism (TP, Alb and UAc) were increased in broilers fed heat-treated soybean meals compared to control. Total proteins in the bloodstream are a currently used parameter to estimate body condition in birds, and when taken together, TP and Alb are indicative of the protein synthesis (12). In the present study, all groups fed heat-treated meal presented significantly higher concentrations of TP and Alb in the bloodstream than Ctr. In all the groups, the concentration of albumin in plasma followed the TP concentrations. Further it also indicates that heat-treatments were beneficial for the overall protein content or the protein availability of diets, and also that the protein content in the diets was enough to support normal blood indicators for protein metabolism. Similar results have been reported by other researchers which obtained improvement of nitrogen retention in broilers following the soybean processing ( 8 , 15).

Uric acid is a marker for protein catabolism. It corresponds to the major avian nitrogenous waste product. Changes in UAc circulating levels reflects the changes occurring in protein catabolism, even if the levels of this molecule may present individual variations in birds under standard management and nutritional conditions according to the protein content or the protein quality of the diet $(12,21)$. Further, UAc concentrations are directly proportional to de grasa endógena y su cantidad está correlacionada con la capacidad de depositar grasa $(12,19)$. En este estudio, sin embargo, no se encontraron diferencias entre los tratamientos de soya, valores absolutos reducidos fueron hallados en harina de autoclave e irradiación por micro onda en comparación con la harina tostada. Además, las concentraciones VLDL en la sangre fueron más bajos que los reportados en grupos de control de otro estudio desarrollado en condiciones ambientales y dietéticas similares (14). Una reducción VLDL se asocia con un descenso en la expresión hepática y la actividad de enzimas lipogenicas que provocan una alteración en el metabolismo de lípidos en el hígado y una reducción del síntesis de novo de ácidos grasos (19).

Las concentraciones en plasma e índices HDL/LDL obtenidos sugieren una disponibilidad limitativa de lípidos para deposición de grasa abdominal en todos los grupos, incluido el grupo de control. Este hecho es apoyado indirectamente por los aumentos registrados en el peso corporal de los pollitos, en particular los con harina tratada de manera térmica, puesto que un perfil reducido de lípido en la sangre ha sido asociado con un aumento en el peso del musculo del pecho y una reducción en el contenido de grasa abdominal (20).

Todos los metabolitos generalmente usados como marcadores para el metabolismo de proteína (TP, Alb y UAc) aumentaron en pollos de engorde alimentados con harina de soya tratamiento térmico en comparación al grupo de control. El total de proteínas en la sangre son un parámetro usado para estimar la condición corporal en aves, y cuando son vistos juntos, TP y Alb son indicativos de una síntesis de proteína (12). En este estudio, todos los grupos alimentados con harina tratada térmica presentaron concentraciones significantemente más altas de TP y Alb en la sangre que Ctr. En todos los grupos, la concentración de albumina en plasma siguió las concentraciones de TP. Además, indica que los tratamientos térmicos fueron beneficios para el contenido de proteína en general o la disponibilidad de la proteína en dietas, y también que el contenido de proteína en la dieta fue suficiente para apoyar los indicadores normales en la sangre para metabolismo de proteína. Resultados similares se han reportado por otros investigadores que obtuvieron una mejoría de retención de nitrógeno en pollos de engorde después de procesar la soya $(8,15)$.

El ácido úrico es un marcador para catabolismo de proteína. Corresponde a un producto de desecho importante de nitrógeno aviar. Cambios en los niveles de circulación de UAc reflejen los cambios que ocurren en el catabolismo de proteína, aun si los niveles de esta molécula pueden presentar variaciones individuales en aves bajo manejo estándar y condiciones nutricionales según el contenido de proteína o la calidad de proteína 
the weight recorded in birds (2). In the study reported herein, though no statistical differences were found between groups, absolute values for UAC in bloodstream were increased in birds fed heat-treated meals in comparison to $\mathrm{Ctr}$, and the higher increased were found in Aut 2 and $\mathrm{McW}$ meal groups. These results suggest that all the thermal treatments in this study increased the protein biological value, in particular the autoclaving for $30 \mathrm{~min}$ and the microwave irradiation. The presence of anti-nutritional factors in soybean meals, especially trypsin inhibitors, is an important constraint to diet protein availability (22), requesting for the use of an inhibitory treatment to decrease the activity of those substances to increase the nutritional value of the meal.

Minerals are essential for body growth. Further, they are also important players in central physiological and synthetic body processes. In the present experiment, no differences were found between groups in calcium or phosphorus concentrations in blood. Calcium is needed for bone ossification and muscle activity, while phosphorus is a major constituent of phospholipids, therefore being essential for energy accumulation.

In conclusion, the results from this experiment showed that all the tested thermal-treatments of soybean diets were advantageous rather than control (raw soybean) diet, in regard to body weight and concentrations of blood lipids and protein metabolites. Further, these essays also suggest that the heat treatment of soybean meals interferes with lipogenesis, and might reduce the abdominal fat deposition, without disturbing the protein metabolism. Comparison of the final body weight and the variations in blood metabolites demonstrated that the most suitable method for soybean thermal treatment processing was, in a decreasing order: Aut2 $\rightarrow$ McW $\rightarrow$ Brn $\rightarrow$ Aut1.

\section{Acknowledgments}

We are grateful to the Islamic Azad University, Rasht Branch, Rasht, Iran for support. de la dieta $(12,21)$. Además, las concentraciones UAc son directamente proporcionales al peso registrado en las aves (2). En este estudio, aunque no se encontraron diferencias estadísticas entre los grupos, los valores absolutos para UAc en la sangre aumentaron en aves alimentadas con harina con tratamiento térmico comparado a Ctr, y el aumento mayor se encontró en los grupos Aut2 y McW. Estos resultados sugieren que todos los tratamientos térmicos en este estudio aumentaron el valor biológico de proteína, en particular el autoclave por $30 \mathrm{~min}$ y la irradiación de micro onda. La presencia de factores anti-nutricionales en harina de soya, especialmente inhibidores tripsina, son una importante limitación a la disponibilidad de proteína en la dieta (22), necesitando el uso de un tratamiento inhibidor para reducir la actividad de esas substancias para aumentar el valor nutricional del alimento.

Los minerales son esenciales para el crecimiento corporal. Adicionalmente, son factores importantes en los procesos corporales fisiológicos centrales y sintéticos. En este experimento, no se encontraron diferencias entre los grupos en las concentraciones sanguíneas de calcio o fosforo. Se necesita calcio para la osificación del hueso y la actividad muscular, mientras que el fosforo es un constituyente importante de fosfolípidos, siendo esencial para acumular energía.

En conclusión, los resultados de este experimento mostraron que todos los tratamientos térmicos de harina de soya probados fueron de ventaja sobre la dieta de control (soya cruda) en lo que tiene que ver con peso corporal y concentraciones de lípidos y metabolitos de proteína sanguínea. Además, estos ensayos sugieren que el tratamiento térmico de harina de soya interfiere con la lipogenesis, y puede reducir la deposición de grasa abdominal sin perturbar el metabolismo de proteína. Comparar el peso corporal final y las variaciones en metabolitos sanguíneos demostró que el método más adecuado para el tratamiento térmico de soya fue, en orden descendiente: Aut2 $\rightarrow \mathrm{McW} \rightarrow \mathrm{Brn} \rightarrow$ Aut1.

\section{Agradecimientos}

Agradecemos a la Islamic Azad University, sede Rasht, Rasht, Iran por su apoyo.

\section{REFERENCES}

1. Wirsenius S, Azar C, Berndes G. How much land is needed for global food production under scenarios of dietary changes and livestock productivity increases in 2030? Agric Sys 2010; 103:621-638.
2. Sandt Pessôa GB, Tavernari FC, Vieira RA, Texeira Albino LA. New concepts in poultry nutrition. Rev Bras Saúde Prod Anim 2012; 13:755-774. 
3. LutfulKabir SM. The Role of Probiotics in the Poultry Industry. Int J Mol Sci 2009; 10:35313546.

4. Ahmed ME, Abdelati KA. Effect of dietary levels of processed Leucaena leucocephala seeds on broiler performance and blood parameters. Int J Poult Sci 2008; 7:423-428.

5. Nahavandinejad M, Seidavi AR, Asadpour L. Effects of soybean meal processing method on the broiler immune system. Kafkas Univ Vet Fakultesi Dergisi 2012a; 18(6):965-972.

6. Maxwell MH, Spence S, Robertson GW, Mitchell MA. Haematological and morphological responses of broiler chicks to hypoxia. Avian Pathol 1990; 19: 23-40.

7. SAS. Versión 8.0 Edition. Cary (NC): SAS institute Inc; 2009.

8. Zhaleh S, Golian A, Hassanabadi A, Mirghelenj SA. Main and interaction effects of extrusion temperature and usage level of full fat soybean on performance and blood metabolites of broiler chickens. African J Biotech 2012; 11(87): 15380-15386.

9. Nahavandinejad M, Seidavi AR, Asadpour L, Temperature treatment of soybean meal on intestinal microbial flora in broilers. African J Mic Res 2012b; 6(26):5464-5471.

10. Musa HH, Chen GH, Cheng JH, Yousif GM. Relation between abdominal fat and serum cholesterol, triglycerides, and lipoprotein concentrations in chicken breeds. Turkish J Vet Anim Sci 2007; 31:375-379.

11. Hernawan E, Wahyuni S, Suprapti H. The levels of blood glucose, triglyceride, final body weight and abdominal fat percentage of broiler under sex-separated and straight run rearing system. Lucrări Ştiinţifice-Seria Zootehnie 2012; 57(17):28-33.

12. Piotrowska A, Burlikowska K, Szymeczko R. Changes in blood chemistry in broiler chickens during the fattening period. Folia Biol Krakow 2011; 59(3-4):183-187.

13. Zhao JP, Chen JL, Zhao GP, Zheng MQ, Jiang RR, Wen J. Live performance, carcass composition, and blood metabolite responses to dietary nutrient density in two distinct broiler breeds of male chickens. Poult Sci 2009; 88:2575-2584.
14. Jahanpour $H$, Seidavi AR, Qotbi AAA, Payan-Carreira R. Effects of Two Levels of Quantitative Feed Restriction for a 7- or 14Days Period on Broilers Blood Parameters. Acta Sci Vet 2013; 41(1144):1-11.

15. Palacios MF, Easter RA, Soltwedel KT, Parsons CM, Douglas MW, Hymowitz T, Pettigrew JE. Effect of soybean variety and processing on growth performance of young chicks and pigs. J Anim Sci 2004; 82(4):1108-1114.

16. Karr-Lilienthal LK, Grieshop CM, Merchen NR, Mahan DC, Faheyjr GC. Chemical composition and protein quality comparisons of soybeans and soybean meáis from five leading soybeanproducing countries. J Agri Food Chem 2004; 52: 6193-6199.

17. Fante CA, Goulart PFP, Alves JD, Henrique $P C$, Fries DD. Isoflavone and protein content in soybeans grains submitted to flooding at different stages of development. Ciência Rural 2011; 41(12):2224-2229.

18. Yang YX, Guo J, Yoon SY, Jin Z, Choi JY, Piao XS, Kim BW, Ohh SJ, Wang MH, Chae BJ. Early energy and protein reduction: effects on growth, blood profiles and expression of genes related to protein and fat metabolism in broilers. Br Poult Sci 2009; 50(2):218-227.

19. Alvarenga RR, Zangeronimo MG, Pereira LJ, Rodrigues PB, Gomide EM. Lipoprotein metabolism in poultry. World's Poult Sci J $2011 ; 67: 431-440$.

20. Saleh AA, Eid $Y Z$, Ebeid TA, Ohtsuka A, Hioki $\mathrm{K}$, Yamamoto M, Hayashi K. The modification of the muscle fatty acid profile by dietary supplementation with Aspergillusawamori in broiler chickens. Br J Nutr 2012; 108(9):15961602.

21. Polat U, Cetin M, Ak I, Balci F. Detection of serum protein fractions and their concentrations in laying and non-laying ostriches (Struthiocamelus) fed with different dietary protein levels. Revue Méd Vét 2004; 155(11):570-574.

22. Clarke E, Wiseman J. Effects of extrusion conditions on trypsin inhibitor activity of full fat soybeans and subsequent effects on their nutritional value for young broilers. Br Poult Sci 2007; 48(6):703-712. 